\title{
Complete genome sequence of 'Halanaeroarchaeum sulfurireducens' M27-SA2, a sulfur-reducing and acetate-oxidizing haloarchaeon from the deep-sea hypersaline anoxic lake Medee
}

\author{
Enzo Messina', Dimitry Y. Sorokin ${ }^{2,3}$, Ilya V. Kublanov², Stepan Toshchakov ${ }^{4}$, Anna Lopatina ${ }^{5}$, Erika Arcadi ${ }^{1}$, \\ Francesco Smedile ${ }^{1}$, Gina La Spada', Violetta La Cono ${ }^{1}$ and Michail M. Yakimov ${ }^{1 *}$
}

\begin{abstract}
Strain M27-SA2 was isolated from the deep-sea salt-saturated anoxic lake Medee, which represents one of the most hostile extreme environments on our planet. On the basis of physiological studies and phylogenetic positioning this extremely halophilic euryarchaeon belongs to a novel genus 'Halanaeroarchaeum' within the family Halobacteriaceae. All members of this genus cultivated so far are strict anaerobes using acetate as the sole carbon and energy source and elemental sulfur as electron acceptor. Here we report the complete genome sequence of the strain M27-SA2 which is composed of a 2,129,244-bp chromosome and a 124,256-bp plasmid. This is the second complete genome sequence within the genus Halanaeroarchaeum. We demonstrate that genome of 'Halanaeroarchaeum sulfurireducens' M27-SA2 harbors complete metabolic pathways for acetate and sulfur catabolism and for de novo biosynthesis of 19 amino acids. The genomic analysis also reveals that 'Halanaeroarchaeum sulfurireducens' M27-SA2 harbors two prophage loci and one CRISPR locus, highly similar to that of Kulunda Steppe (Altai, Russia) isolate 'H. sulfurireducens' $\mathrm{HSR}^{\top}$. The discovery of sulfur-respiring acetate-utilizing haloarchaeon in deep-sea hypersaline anoxic lakes has certain significance for understanding the biogeochemical functioning of these harsh ecosystems, which are incompatible with life for common organisms. Moreover, isolations of Halanaeroarchaeum members from geographically distant salt-saturated sites of different origin suggest a high degree of evolutionary success in their adaptation to this type of extreme biotopes around the world.
\end{abstract}

Keywords: Sulfur reduction, Strictly anaerobic, Extremely halophilic archaea, Hypersaline lake, Anoxic habitats

\section{Introduction}

'Halanaeroarchaeum sulfurireducens' M27-SA2 was isolated from the deep-sea hypersaline anoxic lake Medee (Ionian Sea, Eastern Mediterranean, water depth $3105 \mathrm{~m})$. Together with other five strains, previously isolated from shallow and terrestrial athalassic hypersaline sites of Russia and Spain [1], this haloarchaeon possesses maximum of 91-93 \% 16S rDNA sequence similarity to the nearest cultured members of Halobacteriaceae. All

\footnotetext{
* Correspondence: michail.yakimov@iamc.cnr.it

${ }^{1}$ Institute for Coastal Marine Environment, CNR, Messina, Italy

Full list of author information is available at the end of the article
}

Halanaeroarchaeum isolates represent a novel type of strictly anaerobic haloarchaea that grow best in $\mathrm{NaCl}$ brines close to saturation and use acetate as sole electron donor and carbon source with elemental sulfur as the only electron acceptor. Little is known about anaerobic sulfur metabolism at saturated salt conditions [2]. There is some evidence suggesting that bacterial sulfate reduction is possible under salt-saturated conditions [3], but sulfur respiration under such conditions has so far been very poorly investigated, except for the 'Halanaeroarchaeum' strain HSR2 $2^{\mathrm{T}}$ and two extremely haloalkaliphilic bacteria of the order Halanaerobiales, Halarsenatibacter silvermanii and Natroniella sulfidigena 

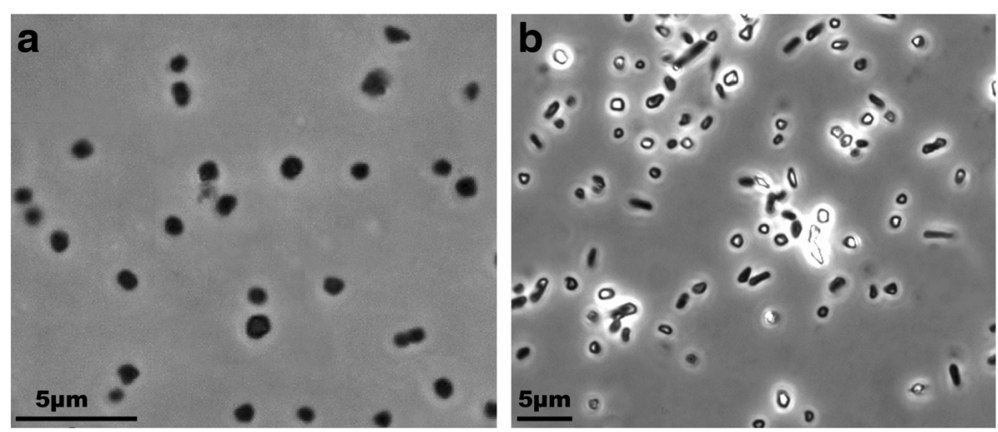

Fig. 1 Morphology of 'Halanaeroarchaeum sulfurireducens' M27-SA2 cells grown on acetate (a) and pyruvate (b) as electron donors and elemental sulphur as electron acceptor. The scale bars represent $5 \mu \mathrm{m}$

$[1,4,5]$. Following the fact, that we were able to isolate these haloarchaea from various geographically and physico-chemically distinct hypersaline sites [1], the sulfidogenic anaerobic oxidation of acetate is likely a common feature in anoxic salt-saturated habitats, overlooked so far.

In this paper we describe the genome properties of 'Halanaeroarchaeum sulfurireducens' M27-SA2 providing details on carbon and sulfur metabolism, on clustered regularly interspaced short palindromic repeats (CRISPR) and on presence of prophage loci and genomic islands.

\section{Organism information}

\section{Classification and features}

'Halanaeroarchaeum sulfurireducens' M27-SA2 has typical haloarchaeal pleomorphic cell morphology, ranging from flattened rods to coccoid or irregular forms (Fig. 1). The pleomorphism of M27-SA2 strain increased with the cultivation time, as is often observed for members of the family Halobacteriaceae. The $16 \mathrm{~S}$ rRNA gene of M27-SA2 exhibited $99.58 \%$ sequence similarity with $H$. sulfurireducens strain HSR2 $2^{\mathrm{T}}$ and $97-98 \%$ sequence similarity with clones of uncultured haloarchaea obtained from

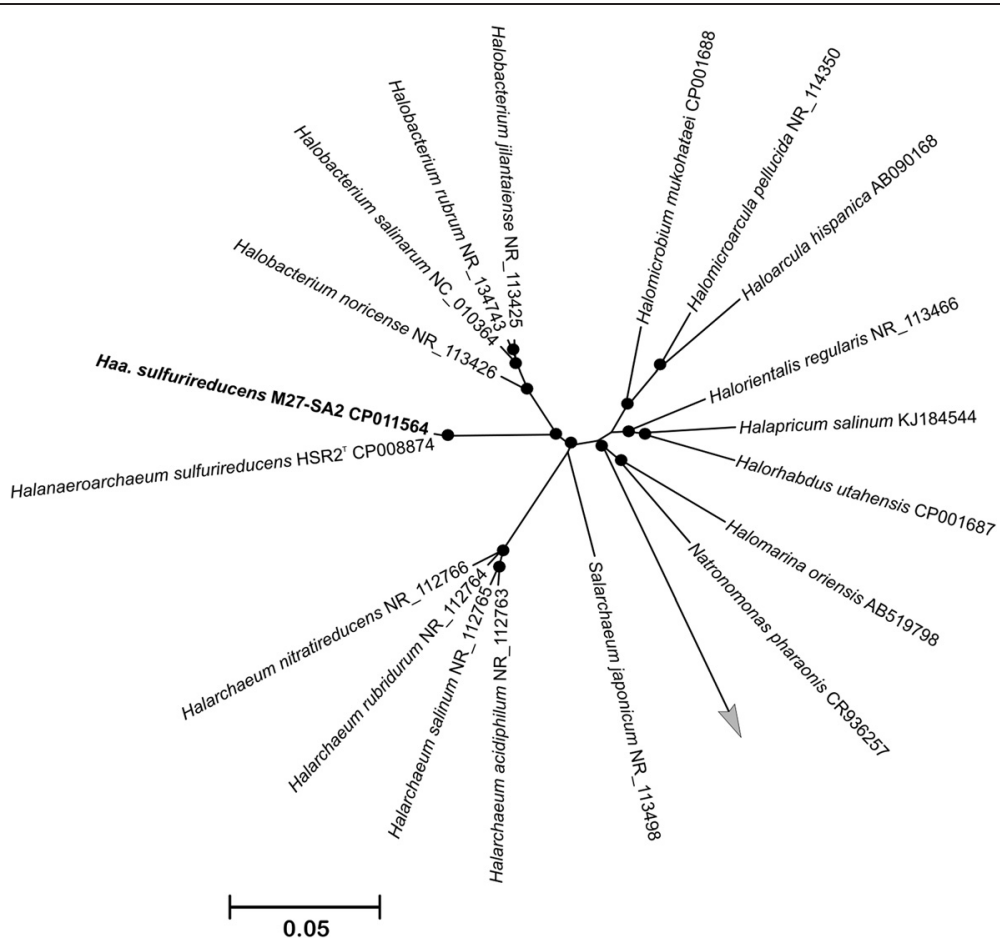

Fig. 2 Phylogenetic tree of 16S rRNA gene sequences showing the position of 'Halanaeroarchaeum sulfurireducens' M27-SA2. Tree was inferred from a $16 \mathrm{~S}$ rRNA gene sequence alignment with PAUP*4.b10 [59] using a LogDet/paralinear distance method. Support for nodes in the tree corresponds to bootstrap values for 1000 pseudo-replicates. Only bootstrap values greater than $75 \%$ are displayed as solid circles. The tree has been arbitrarily rooted on sequence of Natronomonas pharaonis (D87971) and Halomarina oriensis (AB519798). The 16 S rRNA gene sequence of Methanohalophilus halophilus (FN870068) was used as the outgroup. The scale bars represent a $5 \%$ nucleotide sequence divergence 
hypersaline anoxic soils, brines and sediments around the world [1] (Fig. 2).

Together with other Halanaeroarchaeum isolates, M27-SA2 represents the only type of obligate and strictly anaerobic haloarchaea. Most of the known cultivated extremely halophilic euryarchaeota are aerobic heterotrophs except for a few examples of

Table 1 Classification and general features of 'Halanaeroarchaeum sulfurireducens' M27-SA2 ${ }^{\top}$ [48]

\begin{tabular}{|c|c|c|c|c|c|c|}
\hline \multicolumn{4}{|l|}{ Unumrte } & \multirow{3}{*}{\multicolumn{3}{|c|}{$\begin{array}{l}\mathrm{NaCl} 200 \mathrm{~g} \mathrm{l}^{-1} ; \mathrm{KH}_{2} \mathrm{PO}_{4} 0.33 \mathrm{~g} \mathrm{l}^{-1} \text {; yeast extract } 50 \mathrm{mg} \mathrm{l}^{-1} \text {; } \\
\mathrm{Na}_{2} \mathrm{~S} 0.5 \mathrm{~g} \mathrm{l}^{-1} \text {; acetate } 15 \mathrm{mmol} \mathrm{l}^{-1} ; \mathrm{S}^{\circ} 2.5 \mathrm{~g} \mathrm{l}^{-1}, 10 \mathrm{ml} \mathrm{l}^{-1} \\
\text { trace elements solution (DSMZ medium } 320 \text { ); and }\end{array}$}} \\
\hline MIGS ID & Property & Term & Evidence code $^{a}$ & & & \\
\hline & \multirow[t]{8}{*}{ Classification } & Domain Archaea & TAS [49] & & & \\
\hline & & Phylum Euryarchaeota & TAS [50] & \multirow{8}{*}{\multicolumn{3}{|c|}{$\begin{array}{l}10 \mathrm{ml}^{-1} \text { vitamin solution (DSMZ medium 141); } \mathrm{pH} \\
\text { values were adjusted to } 6.7 \text { corresponding to in situ } \\
\text { values of the brine. Similar to all known 'Halanaer- } \\
\text { oarchaeum' isolates, strain M27-SA2 grew between } \\
\mathrm{pH} 6.7 \text { and } 8.0 \text { (with the optimum at } \mathrm{pH} 7.2-7.5 \text { ), } 3.0 \\
\text { and } 5.0 \mathrm{M} \text { of } \mathrm{NaCl} \text { with the optimum growth ob- } \\
\text { served at total salinity of } 250 \mathrm{~g} \mathrm{l}^{-1} \text {. Notwithstanding } \\
\text { the isolation from the environment with permanent } \\
\text { temperature of } 15{ }^{\circ} \mathrm{C}[10] \text {, strain } \mathrm{M} 27-\mathrm{SA} 2 \text { has the } \\
\text { optimal temperature of growth at } 40{ }^{\circ} \mathrm{C} \text { (Table 1). }\end{array}$}} \\
\hline & & Class Halobacteria & $\operatorname{TAS}[51,52]$ & & & \\
\hline & & Order Halobacteriales & TAS [53-55] & & & \\
\hline & & Family Halobacteriaceae & $\operatorname{TAS}[56,57]$ & & & \\
\hline & & Genus Halanaeroarchaeum & TAS [1] & & & \\
\hline & & $\begin{array}{l}\text { Species 'Halanaeroarchaeum } \\
\text { sulfurireducens' }\end{array}$ & TAS [1] & & & \\
\hline & & $\begin{array}{l}\text { Type strain M27-SA2 } \\
\text { (CP011564, CP011565) }\end{array}$ & TAS [1] & & & \\
\hline & Cell shape & Pleomorphic & TAS [1] & & & \\
\hline & Motility & Non-motile & TAS [1] & \multirow{3}{*}{\multicolumn{3}{|c|}{$\begin{array}{l}\text { The isolate has a very limited metabolic profile re- } \\
\text { stricted to acetate and pyruvate as the only available } \\
\text { sources of carbon and energy and elemental sulfur as } \\
\text { a electron acceptor [1]. Nevertheless, yeast extract } \\
\text { should be added to the medium in concentrations of }\end{array}$}} \\
\hline & Sporulation & Non-sporulating & NAS & & & \\
\hline & $\begin{array}{l}\text { Temperature } \\
\text { range }\end{array}$ & $15-50^{\circ} \mathrm{C}$ & $\operatorname{TAS}[1,10]$ & & & \\
\hline & $\begin{array}{l}\text { Optimum } \\
\text { temperature }\end{array}$ & $40^{\circ} \mathrm{C}$ & TAS [1] & \multirow{2}{*}{\multicolumn{3}{|c|}{$\begin{array}{l}\text { Table } 2 \text { Project information for 'Halanaeroarchaeum sulfurireducens' } \\
\text { M27-SA2 }\end{array}$}} \\
\hline & \multirow{2}{*}{$\begin{array}{l}\text { pH range; } \\
\text { Optimum }\end{array}$} & \multirow[t]{2}{*}{$6.7-8.0 ; 7.2-7.5$} & \multirow[t]{2}{*}{ TAS [1] } & & & \\
\hline & & & & MIGS ID & Property & Term \\
\hline & $\begin{array}{l}\text { Carbon } \\
\text { source }\end{array}$ & Acetate, pyruvate & TAS [1] & MIGS-31 & Finishing quality & Finished \\
\hline MIGS-6 & Habitat & $\begin{array}{l}\text { Hypersaline anoxic lake } \\
\text { sediments (brine) }\end{array}$ & $\operatorname{TAS}[1,10]$ & MIGS-28 & Libraries used & $\begin{array}{l}\text { Illumina standard library, } \\
\text { Miseq Reagent kit v2. }\end{array}$ \\
\hline MIGS-6.3 & Salinity & $3.0-5.0 \mathrm{M} \mathrm{NaCl}$ & TAS [1] & MIGS-29 & $\begin{array}{l}\text { Sequencing } \\
\text { platforms }\end{array}$ & Illumina MiSeq System \\
\hline MIGS-22 & $\begin{array}{l}\text { Oxygen } \\
\text { requirement }\end{array}$ & Strictly anaerobic & TAS [1] & \multirow{3}{*}{$\begin{array}{l}\text { MIGS-31.2 } \\
\text { MIGS-30 } \\
\text { MIGS-32 }\end{array}$} & Fold coverage & 634x chromosome, 691x plasmid \\
\hline \multirow{2}{*}{ MIGS-15 } & \multirow{2}{*}{$\begin{array}{l}\text { Biotic } \\
\text { relationship }\end{array}$} & \multirow{2}{*}{ Free-living } & \multirow{2}{*}{ TAS [1] } & & Assemblers & Velvet 1.2.10, Geneious 7.1 \\
\hline & & & & & \multirow{2}{*}{$\begin{array}{l}\text { Gene calling } \\
\text { method }\end{array}$} & \multirow{2}{*}{$\begin{array}{l}\text { Geneious 7.1, Glimmer 3.02, } \\
\text { tRNAScan-SE }\end{array}$} \\
\hline MIGS-14 & Pathogenicity & Non-pathogen & NAS & & & \\
\hline \multirow[t]{2}{*}{ MIGS-4 } & \multirow{2}{*}{$\begin{array}{l}\text { Geographic } \\
\text { location }\end{array}$} & \multirow{2}{*}{$\begin{array}{l}\text { Lake Medee, Ionian Sea, } \\
\text { Eastern Mediterranean }\end{array}$} & \multirow[t]{2}{*}{$\operatorname{TAS}[1,10]$} & & Locus & HLASA \\
\hline & & & & & GenBank ID & CP011564 (chromosome) \\
\hline MIGS-5 & Sample & 24 September 2012 & $\operatorname{TAS}[1,10]$ & & & CP011565 (plasmid) \\
\hline & C & & & & GenBank date of & $30 / 09 / 2015$ \\
\hline MIGS-4.1 & Latitude & $34^{\circ} 26.250 \mathrm{~N}$ & $\operatorname{TAS}[1,10]$ & & release & \\
\hline MIGS-4.2 & Longitude & $22^{\circ} 19.783 \mathrm{E}$ & $\operatorname{TAS}[1,10]$ & & BIOPROJECT & PRJNA284332 \\
\hline MIGS-4.3 & Depth & $3105 \mathrm{~m}$ & $\operatorname{TAS}[1,10]$ & MIGS-13 & Source material & Isolated from the deep-sea \\
\hline $\begin{array}{l}\text { aEvidence } \\
\text { TAS Tracea } \\
\text { NAS Non-tr } \\
\text { isolated sa } \\
\text { or anecdot }\end{array}$ & $\begin{array}{l}\text { codes - IDA Infer } \\
\text { able Author Stater } \\
\text { raceable Author } \\
\text { ample, but based } \\
\text { tal evidence). The }\end{array}$ & $\begin{array}{l}\text { red from Direct Assay (first time in } \\
\text { ment (i.e., a direct report exists in } \\
\text { Statement (i.e., not directly observ } \\
\text { on a generally accepted property } \\
\text { se evidence codes are from the } G\end{array}$ & $\begin{array}{l}\text { n publication), } \\
\text { the literature), } \\
\text { 'ed for the living, } \\
\text { for the species, } \\
\text { ene Ontology }\end{array}$ & & & $\begin{array}{l}\text { Sea, Eastern Mediterranean, } \\
\text { water depth } 3105 \text { m. Salinity: } \\
230 \mathrm{~g} / \mathrm{l} ; \mathrm{pH} \text { 6.8. Coordinates } \\
34^{\circ} 26.250 \mathrm{~N}, 22^{\circ} 19.783 \mathrm{E} .\end{array}$ \\
\hline $\begin{array}{l}\text { project }[58 \\
\text { for a live is } \\
\text { acknowled }\end{array}$ & $\begin{array}{l}\text { 3]. If the evidence } \\
\text { solate by one of } t \\
\text { dgements }\end{array}$ & $\begin{array}{l}\text { DA, then the property was dir } \\
\text { authors or an expert mentione }\end{array}$ & $\begin{array}{l}\text { ly observed } \\
\text { in the }\end{array}$ & & Project relevance & $\begin{array}{l}\text { Extremophile hypersaline } \\
\text { environments }\end{array}$ \\
\hline
\end{tabular}

facultatively anaerobic species capable of growth by fermentation [6], denitrification [7], fumarate, DMSO and TMAO reduction $[8,9]$. Strain M27-SA2 was isolated from the brine (320 $\mathrm{g} \mathrm{l}^{-1}$ of total salt content) of deep-sea Lake Medee (Eastern Mediterranean) collected in September 2012 at depth of 3,010 m. The collected Medee brine was transferred into the serum vials $(120 \mathrm{ml})$ prefilled with the artificial brine to attain $230 \mathrm{~g} \mathrm{l}^{-1}$ of final salinity. The artificial brine has the following composition: $\mathrm{NaCl} 200 \mathrm{~g} \mathrm{l}^{-1} ; \mathrm{KH}_{2} \mathrm{PO}_{4} 0.33 \mathrm{~g} \mathrm{l}^{-1}$; yeast extract $50 \mathrm{mg} \mathrm{l}^{-1}$; $\mathrm{Na}_{2} \mathrm{~S} 0.5 \mathrm{~g} \mathrm{l}^{-1}$; acetate $15 \mathrm{mmol} \mathrm{l}^{-1}$; $\mathrm{S}^{\circ} 2.5 \mathrm{~g} \mathrm{l}^{-1}, 10 \mathrm{ml} \mathrm{l}^{-1}$ trace elements solution (DSMZ medium 320); and $10 \mathrm{ml} \mathrm{l}^{-1}$ vitamin solution (DSMZ medium 141); $\mathrm{pH}$ values were adjusted to 6.7 corresponding to in situ values of the brine. Similar to all known 'Halanaeroarchaeum' isolates, strain M27-SA2 grew between $\mathrm{pH} 6.7$ and 8.0 (with the optimum at $\mathrm{pH} 7.2-7.5$ ), 3.0 and $5.0 \mathrm{M}$ of $\mathrm{NaCl}$ with the optimum growth observed at total salinity of $250 \mathrm{~g} \mathrm{l}^{-1}$. Notwithstanding the isolation from the environment with permanent a electron acceptor [1]. Nevertheless, yeast extract

Table 2 Project information for 'Halanaeroarchaeum sulfurireducens' M27-SA2 
at least $10 \mathrm{mg} \mathrm{l}^{-1}$, as supplemental source of some amino acids, vitamins and cofactors which M27-SA2 likely cannot synthetize.

\section{Genome sequencing information Genome project history}

'Halanaeroarchaeum sulfurireducens' strain M27-SA2 was selected for sequencing on the basis of its phylogenetic positions, its particular feature as a novel strictly anaerobic haloarchaeon from the deep-sea anoxic salt-saturated lake and the interest of studying this unique mechanism of anaerobic respiration, recently discovered for the first time among entire Archaea domain [1]. The respective genome project is deposited on the NCBI BioProject PRJNA284332 and the complete genome sequence in GenBank CP011564 and CP011565 (chromosome and plasmid) is available since 30 of September 2015. The main project information is summarized in Table 2.

\section{Growth conditions and genomic DNA preparation}

Strain M27-SA2 was routinely grown anaerobically to early stationary phase in 120 -ml flasks using a protocol described elsewhere [1]. Genomic DNA was isolated from the cell paste according to extraction method from Urakawa et al. [11]. DNA quality and quantity were determined with a Nanodrop spectrometer (Thermo Scientific, Wilmington, USA).

\section{Genome sequencing and assembly}

The M27-SA2 genome was sequenced with MiSeq System technology of Illumina Inc. (San Diego, CA, USA) using paired-end 250-bp reads. The library was prepared from $1 \mu \mathrm{g}$ of genomic DNA with NEBNext Ultra DNA library preparation kit (NewEngland Biolabs, Ipswich, USA) according to manufacturer's instructions with insert size range of $250-750 \mathrm{bp}$ and maximum of insert size distribution of $470 \mathrm{bp}$. Sequencing run resulted in 6,480,650 paired-end reads with an average read length of $250 \mathrm{bp}$, yielding $1.62 \mathrm{Gbp}$. These reads were assembled using both Velvet 1.2.10 [12] and Geneious 7.1 software. Gaps between contigs were closed with a conventional PCR-based gap closure approach and supported by manual refining with Geneious 7.1 embedded tools, resulting in a fully closed circular chromosome of 2,129,244 bp, and a circular plasmid

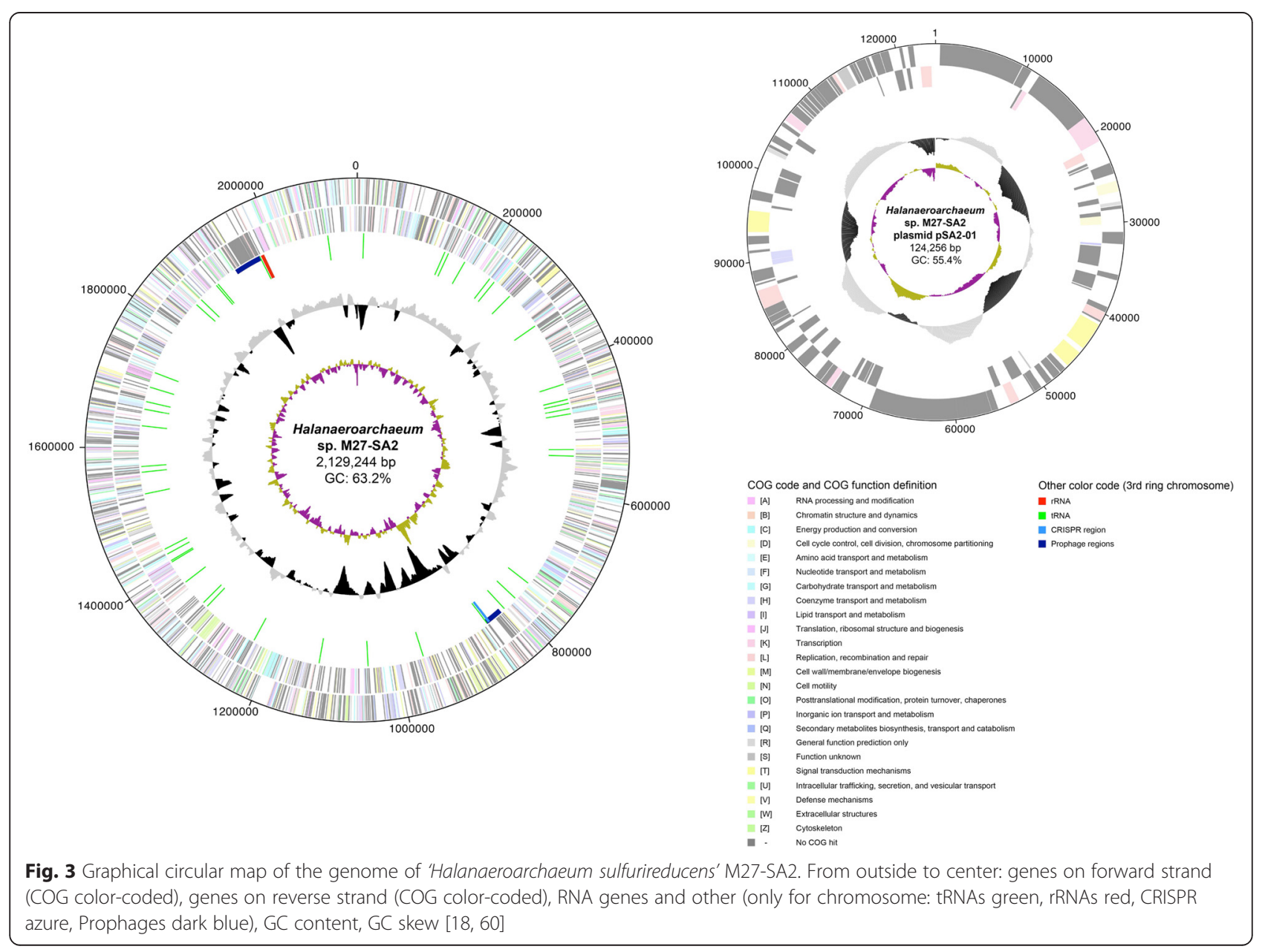


Table 3 Genome composition for 'Halanaeroarchaeum sulfurireducens' M27-SA2

\begin{tabular}{lclll}
\hline Label & Size $(\mathrm{Mb})$ & Topology & INSDC identifier & RefSeq ID \\
\hline Chromosome & 2.129 & circular & CP011564.1 & NZ_CP011564.1 \\
Plasmid & 0.124 & circular & CP011565.1 & NZ_CP011565.1 \\
\hline
\end{tabular}

of $124,256 \mathrm{bp}$. Together, all matching sequences provided $634 \times$ coverage for chromosome and $691 \times$ for plasmid.

\section{Genome annotation}

Protein-coding genes were predicted by Glimmer 3.02 [13]; rRNA genes by RNAmmer 1.2 Server online tool [14]; tRNA-coding sequences by tRNAscan-SE 1.21 online tool [15]; while operon prediction was performed by the FgenesB online tool [16]. Some of structural and functional annotations were performed as it was described by Toshchakov et al. [17]. For each predicted gene similarity search was performed by Geneious 7.1 BLAST embedded tool against public amino acid sequence databases ( $\mathrm{nr}$, SwissProt), conserved domains families databases (Pfam, COG). Finally, annotations were manually curated using the Artemis 16.0 program [18] and refined for each gene with NCBI blastx against nr database (only for control) [19].

\section{Genome properties}

The genome of strain M27-SA2 comprises two circular replicons: a 2,129,244-bp chromosome and a 124,256-bp plasmid (Fig. 3 and Table 3). The chromosome has a $63.19 \%$ GC content. Of the 2,200 predicted genes
Table 5 Number of genes associated with the general COG functional categories for chromosome

\begin{tabular}{llll}
\hline Code & Value & $\%$ age & COG category \\
\hline J & 129 & $5.99 \%$ & Translation, ribosomal structure and biogenesis \\
A & 1 & $0.05 \%$ & RNA processing and modification \\
K & 79 & $3.67 \%$ & Transcription \\
L & 91 & $4.23 \%$ & Replication, recombination and repair \\
B & 3 & $0.14 \%$ & Chromatin structure and dynamics \\
D & 8 & $0.37 \%$ & Cell cycle control, cell division, chromosome \\
& & & partitioning \\
V & 10 & $0.46 \%$ & Defense mechanisms \\
T & 46 & $2.14 \%$ & Signal transduction mechanisms \\
M & 46 & $2.14 \%$ & Cell wall/membrane/envelope biogenesis \\
N & 28 & $1.30 \%$ & Cell motility \\
U & 9 & $0.42 \%$ & Intracellular trafficking, secretion, and vesicular \\
& & & transport \\
O & 58 & $2.70 \%$ & Posttranslational modification, protein turnover, \\
& & & chaperones \\
C & 93 & $4.32 \%$ & Energy production and conversion \\
G & 27 & $1.26 \%$ & Carbohydrate transport and metabolism \\
E & 133 & $6.18 \%$ & Amino acid transport and metabolism \\
F & 52 & $2.42 \%$ & Nucleotide transport and metabolism \\
H & 80 & $3.72 \%$ & Coenzyme transport and metabolism \\
I & 29 & $1.35 \%$ & Lipid transport and metabolism \\
P & 57 & $2.65 \%$ & Inorganic ion transport and metabolism \\
Q & 7 & $0.33 \%$ & Secondary metabolites biosynthesis, transport \\
& & & and catabolism \\
R & 177 & $8.23 \%$ & General function prediction only \\
S & 143 & $6.65 \%$ & Function unknown \\
& 845 & $39.28 \%$ & Not in CoGs \\
\hline & & & \\
& & &
\end{tabular}

Table 4 Chromosome statistics for 'Halanaeroarchaeum sulfurireducens' M27-SA2

\begin{tabular}{lll}
\hline Attribute & Value & \% of total \\
\hline Chromosome size (bp) & $2,129,244$ & \\
DNA coding (bp) & $1,860,079$ & $87.36 \%$ \\
DNA G + C (bp) & $1,345,472$ & $63.19 \%$ \\
Total genes & 2,200 & \\
Protein-coding genes & 2,151 & $97.77 \%$ \\
tRNA genes & 46 & $2.09 \%$ \\
rRNA genes (5S-16S-23S) & 3 & $0.14 \%$ \\
Genes assigned to COGs & 1,306 & $60.72 \%$ \\
CRISPR repeats & 1 & \\
Average length (bp) & 861 & \\
Max length (bp) & 5,619 & $84.33 \%$ \\
ATG initiation codon proteins & 1,814 & $12.93 \%$ \\
GTG initiation codon proteins & 278 & $2.74 \%$ \\
TTG initiation codon proteins & 59 & \\
\hline
\end{tabular}

Table 6 Plasmid statistics for 'Halanaeroarchaeum sulfurireducens' M27-SA2

\begin{tabular}{lll}
\hline Attribute & Value & \% of total \\
\hline Plasmid size (bp) & 124,256 & \\
DNA coding (bp) & 103,887 & $83.61 \%$ \\
DNA G + C (bp) & 68,831 & $55.39 \%$ \\
Total genes & 119 & \\
Protein-coding genes & 119 & $20.16 \%$ \\
Genes assigned to COGs & 24 & \\
Average length (bp) & 873 & \\
Max length (bp) & 4,326 & $65.55 \%$ \\
ATG initiation codon proteins & 78 & $23.53 \%$ \\
GTG initiation codon proteins & 28 & $10.92 \%$ \\
TTG initiation codon proteins & 13 & \\
\hline
\end{tabular}


Table 7 Number of genes associated with the general COG functional categories for plasmid

\begin{tabular}{llll}
\hline Code & Value & $\%$ age & COG category \\
\hline K & 4 & $3.36 \%$ & Transcription \\
L & 7 & $5.88 \%$ & Replication, recombination and repair \\
D & 2 & $1.68 \%$ & $\begin{array}{l}\text { Cell cycle control, cell division, chromosome } \\
\text { partitioning }\end{array}$ \\
& & & T \\
H & 4 & $3.36 \%$ & Signal transduction mechanisms \\
P & 1 & $1.68 \%$ & Coenzyme transport and metabolism \\
R & 2 & $1.68 \%$ & General function prediction only \\
S & 2 & $1.68 \%$ & Function unknown \\
- & 95 & $79.84 \%$ & Not in COGs \\
\hline
\end{tabular}

(88.36 \% of coding density), 2,151 were protein coding genes $(84.3 \%$ started with an ATG codon, $12.9 \%$ with a GTG, and $2.7 \%$ with a TTG), and 49 RNAs genes (a single rRNA operon and 46 tRNAs, see Table 4). The majority of the protein-coding genes $(60.72 \%)$ were assigned with a putative function, while remaining sequences were annotated as hypothetical proteins. An assignment of genes by COGs functional categories is presented in Table 5. The plasmid has $55.39 \%$ GC content and contains 119 protein-coding genes. Only 24 of them (20.16\%) were assigned to COGs (Table 6 and Table 7) while the remaining genes were annotated as hypothetical proteins.

\section{Insights from the genome sequence Genome comparisons: M27-SA2 vs HSR2 ${ }^{\top}$}

As a demonstration of their extreme similarity, the genomes of 'Halanaeroarchaeum sulfurireducens' M27-SA2 and 'Halanaeroarchaeum sulfurireducens' $\mathrm{HSR} 2^{\mathrm{T}}$, were compared with three different methods: the Artemis Comparison Tool program [20], the LAST web service [21], and the Multiple Genome Alignment system software (Mauve) [22]. Additionally, Double ACT web service was used to generate the required ACT comparison file. The results of these tools are shown in Fig. 4. It follows that the chromosome of M27-SA2 has high average nucleotide identities, over $97 \%$, to the corresponding replicon of $\mathrm{HSR}^{2}$, whereas the plasmids of both isolates possess even higher average nucleotide identities values, over $99 \%$. The only difference with respect to the HSR2 ${ }^{\mathrm{T}}$ chromosome (the gap visible for all methods used) was due to the

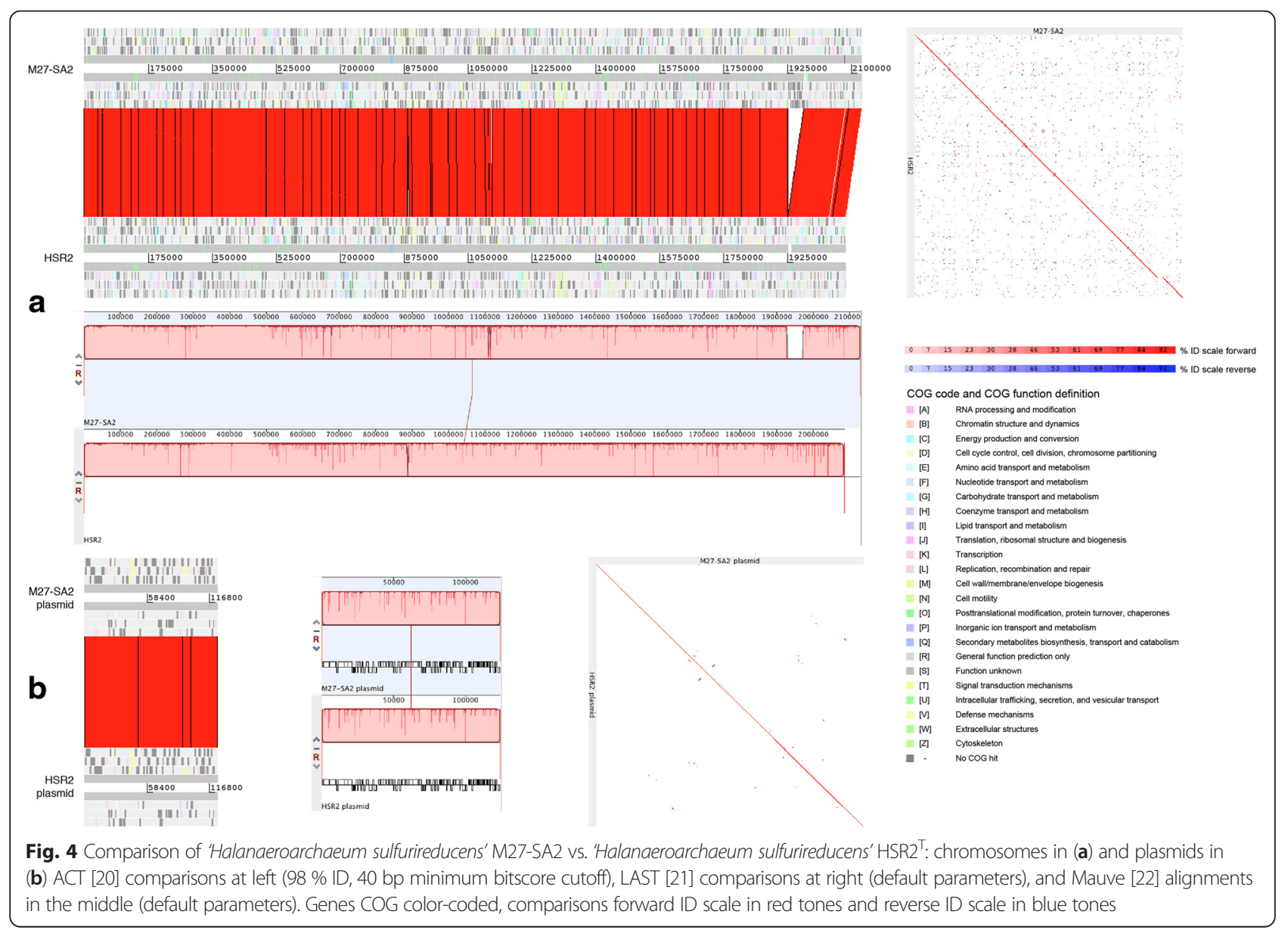




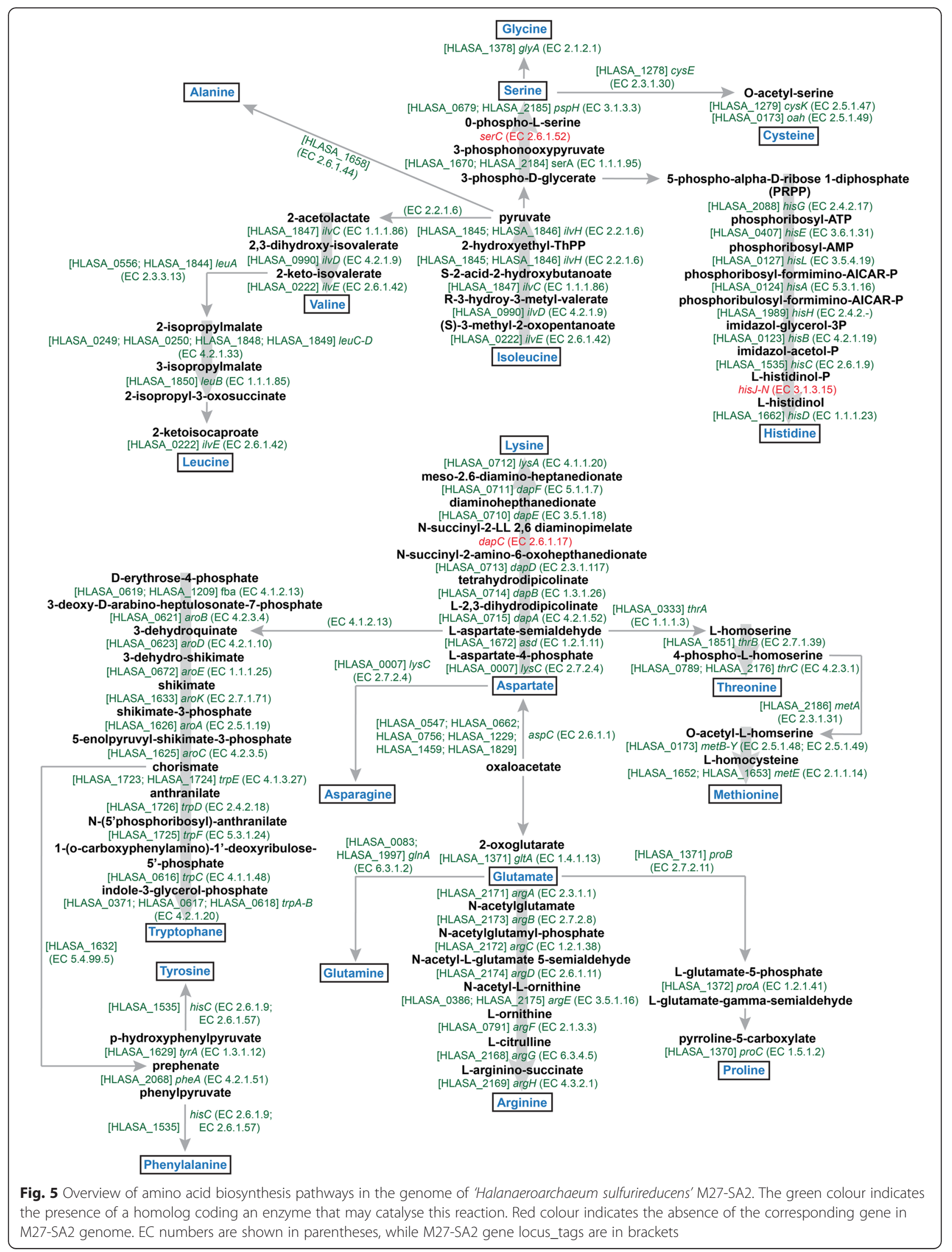


presence of an extra phage-like region (prophage 2, see Phage-like elements below). Similarly to what was found in HSR2 $^{\mathrm{T}}$, the genome analysis of M27-SA2 identified two blocks of genes responsible for the oxidation of acetate to $\mathrm{CO}_{2}$ with elemental sulfur as the electron acceptor. The acetate oxidation pathway occurred by means of an ATPdependent acetyl-CoA synthase and TCA cycle, while sulfur dissimilation could be accomplished by four different operons, coding for molybdopterin oxidoreductases (HLASA_0051-0056; HLASA_0525-0529; HLASA_06880694; HLASA_1275-1271). Notwithstanding, these two strains were isolated apparently from very different and geographically very distant habitats, e.g. top $10 \mathrm{~cm}$-layer sediments of Kulunda Steppe (Central Russia) terrestrial hypersaline lakes $\left(\mathrm{HSR}^{\mathrm{T}}\right)$, and from hypersaline brine at $3105 \mathrm{~m}$ depth of Lake Medee (Eastern Mediterranean) M27-SA2, we failed to find any genetic determinants reflecting such significant difference in environmental settings of these two habitats.

\section{Amino acid biosynthesis pathways}

The addition of yeast extract in amounts $10-20 \mathrm{mg} \mathrm{l}^{-1}$ is necessary for growth of strain M27-SA2, which is likely indicating that some amino acids are not synthesized or their biosynthesis could be arduous and they should be imported from the environment. We reconstructed the amino acid biosynthetic pathways of M27-SA2 using both the SEED subsystem [23] and KEGG orthology [24] assignments (Fig. 5). Similarly to what found on strain

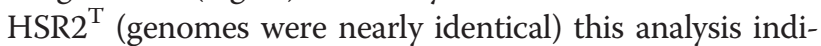
cated that the genome of strain M27-SA2 harbors all the genes required for complete synthesis of at least 19 amino acids. Seven of the eight genes involved in conversion of aspartate to lysine via tetrahydrodipicolinate, which should involve succinylated intermediates, were found. The gene dapC encoding $\mathrm{N}$-succinyldiaminopimelateaminotransferase was not identified in M27-SA2 genome.
The pathway for the biosynthesis of isoleucine, valine, and leucine from pyruvate seems to be fully present and all genes were detected in the analyzed genome. Interestingly, a branched-chain amino acid transport system related to the permease protein Liv (HLASA_0776-0780), was detected in the M27-SA2 genome, suggesting that nonsecreted amino acids could be imported via various transporters.

\section{CRISPR analysis}

Pilercr v1.02 [25] with default parameters was used to identify Clustered Regularly Interspaced Short Palindromic Repeats array in M27-SA2 genome. The CRISPRfinder tool was used for CRISPR search as a control [26]. Cas genes were identified with the NCBI Blastn online tool [19]. Spacer sequences detected in CRISPR array were analyzed in order to find similarities with plasmids, phages or haloarchaeal chromosomes. Spacer sequences were blasted against nt, env_nt and wgs databases using NCBI BLAST+ blastn tool installed into web-based Galaxy platform. Additionally, spacer sequences were blasted against a local database made of several hypersaline metagenomes, including those from the anoxic hypersaline lakes Kryos (M. Yakimov, unpublished results) and Thetis [27], the hypersaline Australian lake Tyrrell [28], and solar salterns of Santa Pola [29] and South Bay Salt [30]. Spacers with $\leq 7$ SNPs (80 \% match or 30/37 nucleotides) were considered as positive hits. Obtained matches of at least $100 \mathrm{bp}$-long were compared to the $\mathrm{nr}$ and nt NCBI databases using NCBI Blast + blastx and blastn, respectively.

Most sequenced so far archaeal genomes contain at least one CRISPR-Cas system [26]. DNA fragment of $13.1 \mathrm{kbp}$ that included CRISPR array and associated cas genes was detected in the M27-SA2 genome. The CRISPR array found in M27-SA2 was practically identical to that found in 'Halanaeroarchaeum sulfurireducens' $\mathrm{HSR}^{\mathrm{T}}{ }^{\mathrm{T}}$, contained the same 30-bp direct

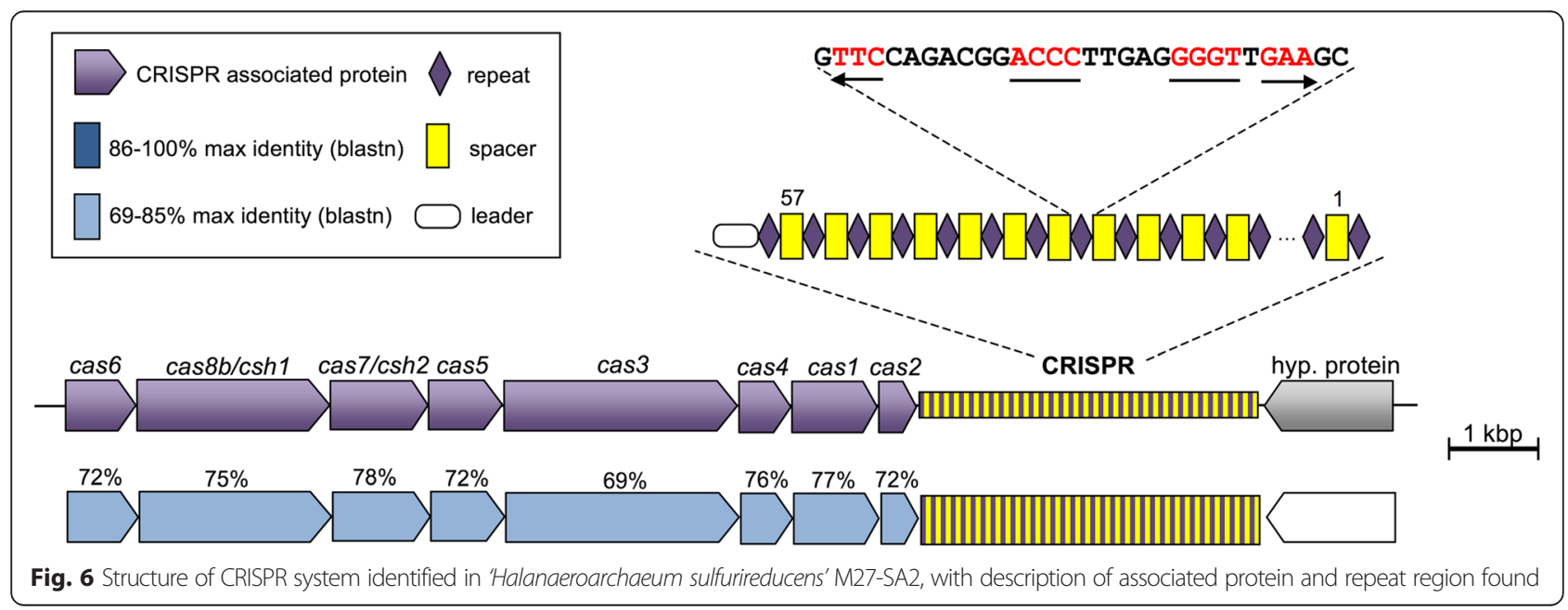


Table 8 CRISPR spacers analysis in the chromosome of 'Halanaeroarchaeum sulfurireducens' M27-SA2

\begin{tabular}{lllll}
\hline Spacer \# & Match to metagenomic library & \# of mismatches & 5' PAM sequence & Match to GenBank nt database \\
\hline 7 & Lake Tyrrell (SRR402046) & 4 & TTT & gb|JQ807236.1|, environmental Halophage eHP-15 \\
24 & Lake Tyrrell (SRR402045) & 3 & CTC/TGC & no \\
34 & Lake Tyrrell (SRR402046) & 2 & TTC/TT & no \\
37 & Lake Kryos (unpublished) & 0 & & gb|AY596293.1|, Haloarcula marismortui ATCC 43049 \\
& & & & plasmid pNG400, CRISPR array \\
52 & Lake Tyrrell (SRR402046) & 5 & GTG & no \\
54 & Lake Tyrrell (SRR402045) & 5 & TTC & no \\
\hline
\end{tabular}

repeat sequence $\left(5^{\prime}\right.$ - GTTCCAGACGGACCCTTGAG GGGTTGAAGC $-3^{\prime}$ ), and carried 57 spacers instead of 55 detected in $\mathrm{HSR}^{\mathrm{T}}$, with an average length of 37 nucleotides (individual spacer length ranged from $35 \mathrm{bp}$ to $43 \mathrm{bp})$. Similarly, eight cas vgenes were detected in vicinity of the CRISPR array: cas6, cas $8 b /$ csh1, cas7/csh2, cas5, cas 3 , cas4, cas 1 , cas2 (Fig. 6). All cas genes had high level of similarity to cas genes of Halorhabdus tiamatea and Haloarcula argentinensis (with e-value ranged from $1 \mathrm{e}^{-37}$ to 0.0 ), and thus were highly conserved between closely relative haloarchaeal genera. According to the current classification, this system was affiliated to I-B subtype or CASS7 [31].

BLASTn analysis of repeat sequence of M27-SA2 revealed several matches to haloarchaeal genomes with identical or similar (up to 3 mismatches) sequences of repeats: Natronomonas pharaonis DSM 2160 plasmid PL131, Haloarcula marismortui ATCC 43049 plasmid pNG300, Haloarcula hispanica N601 plasmid pHH126 and Halorhabdus tiamatea SARL4B.

Spacers extracted from 'Halanaeroarchaeum sulfurireducens' M27-SA2 were identical to that found in HSR2 ${ }^{\mathrm{T}}$, although two spacers (\#36 and \#37) were found only in M27-SA2.

When we compared 57 spacers extracted from 'Halanaeroarchaeum sulfurireducens' M27-SA2 to nt, env_nt and wgs Genbank databases, no matches were obtained. We blasted the spacers against metagenomic sequences of samples obtained from aforementioned hypersaline lake environments. This analysis identified six spacers that matched the metagenomic sequences (protospacers) obtained from the salt-saturated lakes

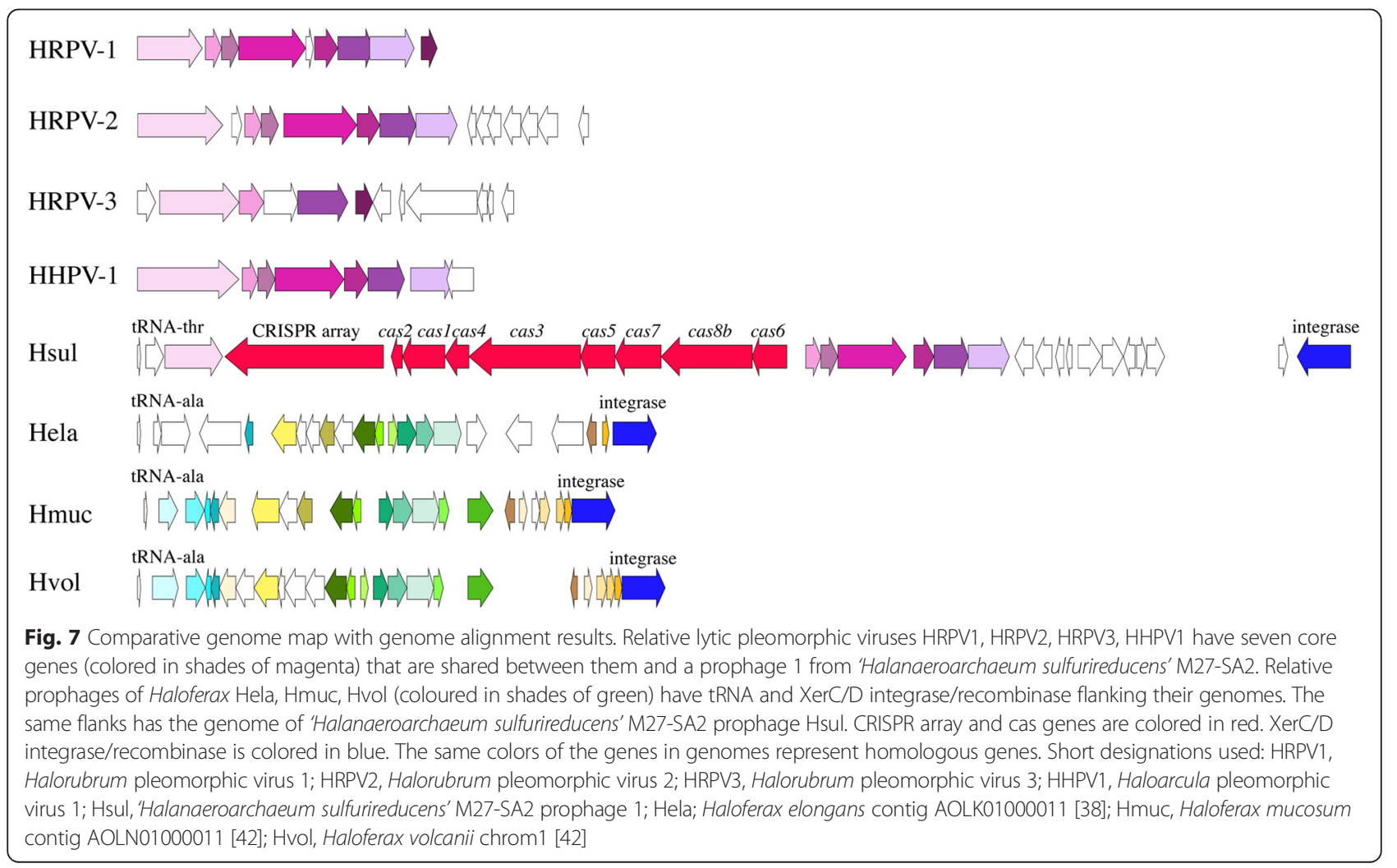


Kryos and Tyrrel (Table 8). Spacer \#37 matched to DNA fragment from lake Kryos metagenome that contained CRISPR array with repeat type of $H$. marismortui ATCC 43049 plasmid pNG400. These results suggest the occurrence of bacteria or/and viruses transfer between hypersaline biotopes. The spacer \#7 matched to metagenomic sequences from viral fraction of lake Tyrrell. When those reads were compared to nt database, hits to viral contigs eHP-1, eHP-4, eHP-15 and eHP-19 from SantaPola solar saltern [29], and to the sequence of uncultured virus clone from Tunisian solar salterns [32] were found. Four other spacers (\#24, \#34, \#52 and \#54) matched to sequences from viral fraction of metagenome from lake Tyrrell. No homology in the GenBank was found. These results demonstrate that 'Halanaeroarchaeum sulfurireducens' M27-SA2 CRISPR spacers, likewise HSR2 ${ }^{\mathrm{T}}$ CRISPR spacers, target mobile genetic elements that have been identified in distant solar and deep-sea hypersaline lakes, suggesting that this haloarchaeon could have been adapted to yet unexplored haloviruses.

The presence of a short protospacer adjacent motif located upstream of the protospacer is required for immunity of type I CRISPR-Cas system [33]. The PAM sequence varies in different CRISPR subsystems. It has been shown that archaeal I-B CRISPR-Cas system has several different PAM sequences upstream of the protospacer: TTC, ACT, TAA, TAT, TAG and CAC for Haloferax volcani [34], TTC for Haloquadratum walsbyi [34], TTT, TTC, TTG, and CCC for H. hispanica [35]. Our analysis detected several variants of trinucleotide sequence upstream of different protospacers (Table 8). Interestingly, most of them had TTC/TTT sequence, which are highly conserved among archaeal I-B subsystems reported so far [36]. This fact suggests that CRISPR-Cas system is likely active in 'Halanaeroarchaeum sulfurireducens' M27-SA2.

Table 9 NCBI blastp results for prophage 1 region of 'Halanaeroarchaeum sulfurireducens' M27-SA2

\begin{tabular}{|c|c|c|c|c|}
\hline locus_tag & Length (bp) & NCBI blastp best hit & e-value & gb accession \\
\hline HLASA_0843 & 1239 & integrase [Halorhabdus utahensis] & $6.00 e-176$ & WP_015789480.1 \\
\hline HLASA_0844 & 213 & hypothetical protein [Halomicrobium katesii] & $5.00 e-05$ & WP_018258875.1 \\
\hline HLASA_0845 & 417 & DNA-binding protein [Halostagnicola larsenii XH-48] & $1.00 \mathrm{e}-79$ & AHG02386.1 \\
\hline HLASA_0846 & 231 & hypothetical protein [Salinarchaeum sp. Harcht-Bsk1] & $5.00 \mathrm{e}-37$ & WP_020446487.1 \\
\hline HLASA_0847 & 267 & hypothetical protein [uncultured archaeon A07HR60] & $6.00 \mathrm{e}-07$ & WP_023506388.1 \\
\hline HLASA_0848 & 489 & hypothetical protein [Halarchaeum acidiphilum] & $4.00 \mathrm{e}-94$ & WP_020221057.1 \\
\hline HLASA_0849 & 552 & hypothetical protein [Halarchaeum acidiphilum] & $9.00 \mathrm{e}-119$ & WP_044957257.1 \\
\hline HLASA_0850 & 141 & MULTISPECIES: hypothetical protein [Haloarcula] & $2.00 \mathrm{e}-21$ & WP_004594507.1 \\
\hline HLASA_0851 & 189 & hypothetical protein [Haloquadratum walsbyi] & $4.00 \mathrm{e}-33$ & WP_021056874.1 \\
\hline HLASA_0852 & 381 & hypothetical protein [Halorubrum sp. T3] & $2.00 \mathrm{e}-82$ & WP_026046123.1 \\
\hline HLASA_0853 & 423 & hypothetical protein [Halorubrum saccharovorum] & $3.00 \mathrm{e}-44$ & WP_004048594.1 \\
\hline HLASA_0854 & 954 & hypothetical protein [Halomicrobium mukohataei] & $6.00 \mathrm{e}-27$ & WP_015761810.1 \\
\hline HLASA_0855 & 798 & hypothetical protein HRPV-1_gp7 [Halorubrum pleomorphic virus 1] & $2.00 \mathrm{e}-26$ & YP_002791892.1 \\
\hline HLASA_0856 & 474 & unknown [Haloarcula hispanica pleomorphic virus 1] & $6.00 \mathrm{e}-19$ & YP_003411999.1 \\
\hline HLASA_0857 & 1581 & MULTISPECIES: hypothetical protein [Haloferax] & $8.00 \mathrm{e}-52$ & WP_008576942.1 \\
\hline HLASA_0858 & 399 & gp3 [Haloarcula hispanica pleomorphic virus 2] & $6.00 \mathrm{e}-47$ & YP_009008689.1 \\
\hline HLASA_0859 & 351 & hypothetical protein [Haloarcula argentinensis] & $5.00 \mathrm{e}-38$ & WP_005538312.1 \\
\hline HLASA_0860 & 813 & CRISPR-associated protein Cas6 [Halorhabdus tiamatea] & $7.00 \mathrm{e}-151$ & WP_008524857.1 \\
\hline HLASA_0861 & 2112 & CRISPR-associated protein Csh1 [Halorhabdus tiamatea] & 0 & WP_008524855.1 \\
\hline HLASA_0862 & 1068 & CRISPR-associated protein, Csh2 family [Natronorubrum sulfidifaciens] & 0 & WP_008164963.1 \\
\hline HLASA_0863 & 801 & CRISPR-associated protein Cas5 [Halorhabdus tiamatea] & $2.00 \mathrm{e}-124$ & WP_008524852.1 \\
\hline HLASA_0864 & 2589 & CRISPR-associated helicase, Cas3 [Halorhabdus tiamatea] & 0 & WP_020936219.1 \\
\hline HLASA_0865 & 555 & CRISPR-associated protein Cas4 [Halorhabdus utahensis] & $4.00 \mathrm{e}-99$ & WP_015789200.1 \\
\hline HLASA_0866 & 993 & CRISPR-associated protein Cas1 [Halorhabdus utahensis] & 0 & WP_015789199.1 \\
\hline HLASA_0867 & 264 & CRISPR-associated endonuclease Cas2 [Halorhabdus utahensis] & $1.00 \mathrm{e}-37$ & WP_015789198.1 \\
\hline repeat_region & 3798 & CRISPR repeat region & & \\
\hline HLASA_0868 & 1338 & replication-related protein [Natrinema versiforme] & $5.00 e-145$ & WP_006432249.1 \\
\hline HLASA_0869 & 411 & PREDICTED: multidrug and toxin extrusion protein 1 [Cavia porcellus] & 0.1 & XP_003465357.1 \\
\hline
\end{tabular}


Table 10 NCBI blastp results for prophage 2 region of 'Halanaeroarchaeum sulfurireducens' M27-SA2

\begin{tabular}{|c|c|c|c|c|}
\hline locus_tag & Length (bp) & NCBI blastp best hit & e-value & gb accession \\
\hline HLASA_2001 & 1347 & integrase [Natronobacterium gregoryi] & $3.00 \mathrm{e}-178$ & WP_005577816.1 \\
\hline HLASA_2002 & 186 & no & & \\
\hline HLASA_2003 & 1125 & hypothetical protein [Haloferax sp. ATB1] & $5.00 \mathrm{e}-11$ & WP_042662540.1 \\
\hline HLASA_2004 & 996 & zinc finger SWIM domain protein [Haloarcula vallismortis] & $5.00 \mathrm{e}-14$ & WP_004517574.1 \\
\hline HLASA_2005 & 219 & hypothetical protein [Halosimplex carlsbadense] & $4.00 \mathrm{e}-15$ & WP_006885565.1 \\
\hline HLASA_2006 & 1071 & ORC / cell division control protein 6 [Haloarcula amylolytica] & $2.00 \mathrm{e}-98$ & WP_008307569.1 \\
\hline HLASA_2007 & 660 & hypothetical protein [Haloarcula amylolytica] & $9.00 \mathrm{e}-59$ & WP_008312971.1 \\
\hline HLASA_2008 & 978 & hypothetical protein [Haloarcula amylolytica] & $3.00 \mathrm{e}-144$ & WP_008312969.1 \\
\hline HLASA_2009 & 639 & PHP domain-containing protein [Haloarcula amylolytica] & $3.00 \mathrm{e}-106$ & WP_008312967.1 \\
\hline HLASA_2010 & 912 & decaprenyl-phosphate phosphoribosyltransferase [Haloarcula amylolytica] & 0 & WP_008312966.1 \\
\hline HLASA_2011 & 423 & hypothetical protein [Haloarcula vallismortis] & $2.00 \mathrm{e}-29$ & WP_004518340.1 \\
\hline HLASA_2012 & 1092 & NAD-dependent epimerase/dehydratase [Haloarcula amylolytica] & 0 & WP_008312962.1 \\
\hline HLASA_2013 & 1299 & hypothetical protein [Anaerolinea thermophila] & $2.00 \mathrm{e}-35$ & WP_013559525.1 \\
\hline HLASA_2014 & 810 & concanavalin A-like lectin/glucanases family protein [Halorubrum sp. AJ67] & $2.00 \mathrm{e}-18$ & CDK38289.1 \\
\hline HLASA_2015 & 597 & hypothetical protein OSG_eHP34_00135 [Environmental halophage eHP-34] & $1.00 \mathrm{e}-28$ & AFH22760.1 \\
\hline HLASA_2016 & 576 & hypothetical protein HGTV1_28 [halovirus HGTV-1] & $2.00 \mathrm{e}-11$ & YP_008059236.1 \\
\hline HLASA_2017 & 912 & hypothetical protein PhiCh1p32 [Natrialba phage PhiCh1] & $2.00 \mathrm{e}-29$ & NP_665949.1 \\
\hline HLASA_2018 & 1263 & baseplate J protein [haloarchaeon 3A1_DGR] & $2.00 \mathrm{e}-178$ & WP_039401004.1 \\
\hline HLASA_2019 & 363 & hypothetical protein [haloarchaeon 3A1_DGR] & $7.00 \mathrm{e}-15$ & WP_021074727.1 \\
\hline HLASA_2020 & 681 & hypothetical protein [Natrialba magadii] & $3.00 \mathrm{e}-34$ & WP_004268274.1 \\
\hline HLASA_2021 & 879 & hypothetical protein [haloarchaeon 3A1_DGR] & $4.00 \mathrm{e}-97$ & WP_021074730.1 \\
\hline HLASA_2022 & 345 & hypothetical protein [haloarchaeon 3A1_DGR] & $3.00 \mathrm{e}-43$ & WP_039401001.1 \\
\hline HLASA_2023 & 564 & hypothetical protein [haloarchaeon 3A1_DGR] & $1.00 \mathrm{e}-35$ & WP_021075289.1 \\
\hline HLASA_2024 & 3123 & prophage pi3 protein 14 [Halalkalicoccus jeotgali] & $1.00 \mathrm{e}-55$ & WP_008414607.1 \\
\hline HLASA_2025 & 477 & hypothetical protein [haloarchaeon 3A1_DGR] & $1.00 \mathrm{e}-13$ & WP_021074542.1 \\
\hline HLASA_2026 & 1296 & hypothetical protein [haloarchaeon 3A1_DGR] & $2.00 \mathrm{e}-155$ & WP_039400994.1 \\
\hline HLASA_2027 & 588 & hypothetical protein [Natrialba magadi] & $1.00 \mathrm{e}-37$ & WP_004268261.1 \\
\hline HLASA_2028 & 447 & hypothetical protein [haloarchaeon 3A1_DGR] & $1.00 \mathrm{e}-45$ & WP_039400992.1 \\
\hline HLASA_2029 & 285 & hypothetical protein [haloarchaeon 3A1_DGR] & $6.00 \mathrm{e}-29$ & WP_021074547.1 \\
\hline HLASA_2030 & 387 & hypothetical protein EL22_16975 [Halostagnicola sp. A56] & $2.00 \mathrm{e}-05$ & KDE59819.1 \\
\hline HLASA_2031 & 366 & hypothetical protein HHTV1_22 [halovirus HHTV-1] & $2.00 e-05$ & YP_008058712.1 \\
\hline HLASA_2032 & 1140 & major capsid protein go21 [halovirus HHTV-1] & $3.00 \mathrm{e}-91$ & YP_008058711.1 \\
\hline HLASA_2033 & 453 & acyl dehydratase [Haloferax mediterranei] & 0.032 & WP_014732690.1 \\
\hline HLASA_2034 & 1221 & PREDICTED: myosin-9-like [Nelumbo nucifera Gaertn.] & $2.00 \mathrm{e}-04$ & XP_010274858.1 \\
\hline HLASA_2035 & 294 & no & & \\
\hline HLASA_2036 & 216 & no & & \\
\hline HLASA_2037 & 417 & no & & \\
\hline HLASA_2038 & 339 & hypothetical protein [Natronobacterium gregoryi] & 5.00e-09 & WP_005577927.1 \\
\hline HLASA_2039 & 669 & hypothetical protein [Haloterrigena thermotolerans] & $9.00 \mathrm{e}-23$ & WP_006649646.1 \\
\hline HLASA_2040 & 381 & hypothetical protein [Halovivax ruber] & $2.00 \mathrm{e}-08$ & WP_015300135.1 \\
\hline HLASA_2041 & 1605 & uncharacterized protein BN903_58 [Halorubrum sp. AJ67] & $1.00 \mathrm{e}-48$ & CDK39659.1 \\
\hline HLASA_2042 & 1710 & hypothetical protein HALG_00007 [Halorubrum phage CGphi46] & $1.00 \mathrm{e}-131$ & YP_008126542.1 \\
\hline HLASA_2043 & 444 & hypothetical protein HCTV2_15 [halovirus HCTV-2] & $4.00 \mathrm{e}-29$ & YP_008058377.1 \\
\hline HLASA_2044 & 1320 & DNA methylase [Halostagnicola sp. A56] & $4.00 \mathrm{e}-120$ & KDE56926.1 \\
\hline
\end{tabular}


Table 10 NCBI blastp results for prophage 2 region of 'Halanaeroarchaeum sulfurireducens' M27-SA2 (Continued)

\begin{tabular}{|c|c|c|c|c|}
\hline HLASA_2045 & 219 & hypothetical protein OSG_eHP14_00030 [Environmental halophage eHP-14] & $4.00 \mathrm{e}-08$ & AFH21986.1 \\
\hline HLASA_2046 & 171 & hypothetical protein [Haloarcula argentinensis] & $8.00 \mathrm{e}-05$ & WP_005538080.1 \\
\hline HLASA_2047 & 303 & no & & \\
\hline HLASA_2048 & 3660 & hypothetical protein [Natrialba magadi] & 0 & WP_004217537.1 \\
\hline
\end{tabular}

\section{Phage-like elements}

It has been estimated that $60-70 \%$ of prokaryotic genomes deposited to GenBank contain prophage sequences [37]. We analyzed the genome of 'Halanaeroarchaeum sulfurireducens' M27-SA2 in terms of presence of prophages. Apparently, there were two fragments of 28.5 $\mathrm{kbp}$ (prophage 1) and $49.5 \mathrm{kbp}$ (prophage 2) that contained clusters of genes of viral origin. Manual annotation of prophage 1 gave best matches to putative ORFs of haloarchaeal pleomorphic phages HRPV1, HRPV2, HRPV3, HRPV6, HHPV1 and HHPV2 of Haloferax lucentense, pHK2 plasmid, and prophages in the genomes of Halomicrobium mukohataei and Haloferax volcanii. The genome of prophage 1, presents in both M27-SA2 and $\mathrm{HSR}^{\mathrm{T}}$ strains, was located near the tRNA gene, a common site for prophage insertions [38], and contained a putative XerC/D integrase/recombinase gene on the opposite to tRNA gene flank. Presence of an integrase and a tRNA insertion site could be interpreted as indicator of an active prophage. The alignment of the genome of prophage 1 and its closest relatives shows that prophage 1 contains ORFs homologous to the whole set of core genes in the genomes of lytic pleoviruses HRPV-1, HRPV-2, HRPV-3 and HHPV-1 (Fig. 7 and Tables 9 and 10). However, we have found a single CRISPR array and eight associated cas genes of I-B subtype inside the genome of prophage 1 . The insert is $\sim 14 \mathrm{kbp}$ long and occupies half of the prophage 1 genome $(\sim 28.5 \mathrm{kbp})$. Earlier, the entire CRISPR-Cas system including cas genes of I-F type and a CRISPR array was found in the genome of myovirus ICP1 of Vibrio cholera serogroup O1 [39]. Most of the spacers from ICP1 CRISPR array targeted PICI-like element from the genome of $V$. cholera, an excised circular DNA fragment, which becomes induced and interferes with phage reproduction during infection. Therefore, bacteriophages can acquire CRISPR-Cas systems from the host genome or from the environment through natural transformation of the host cell and use it to abolish anti-phage cellular mechanisms. Two opposite suggestions could be made based on the presence of the CRISPR-Cas system in the prophage 1. On one hand, the insert of DNA fragment containing CRISPR-Cas system equal to the length of the

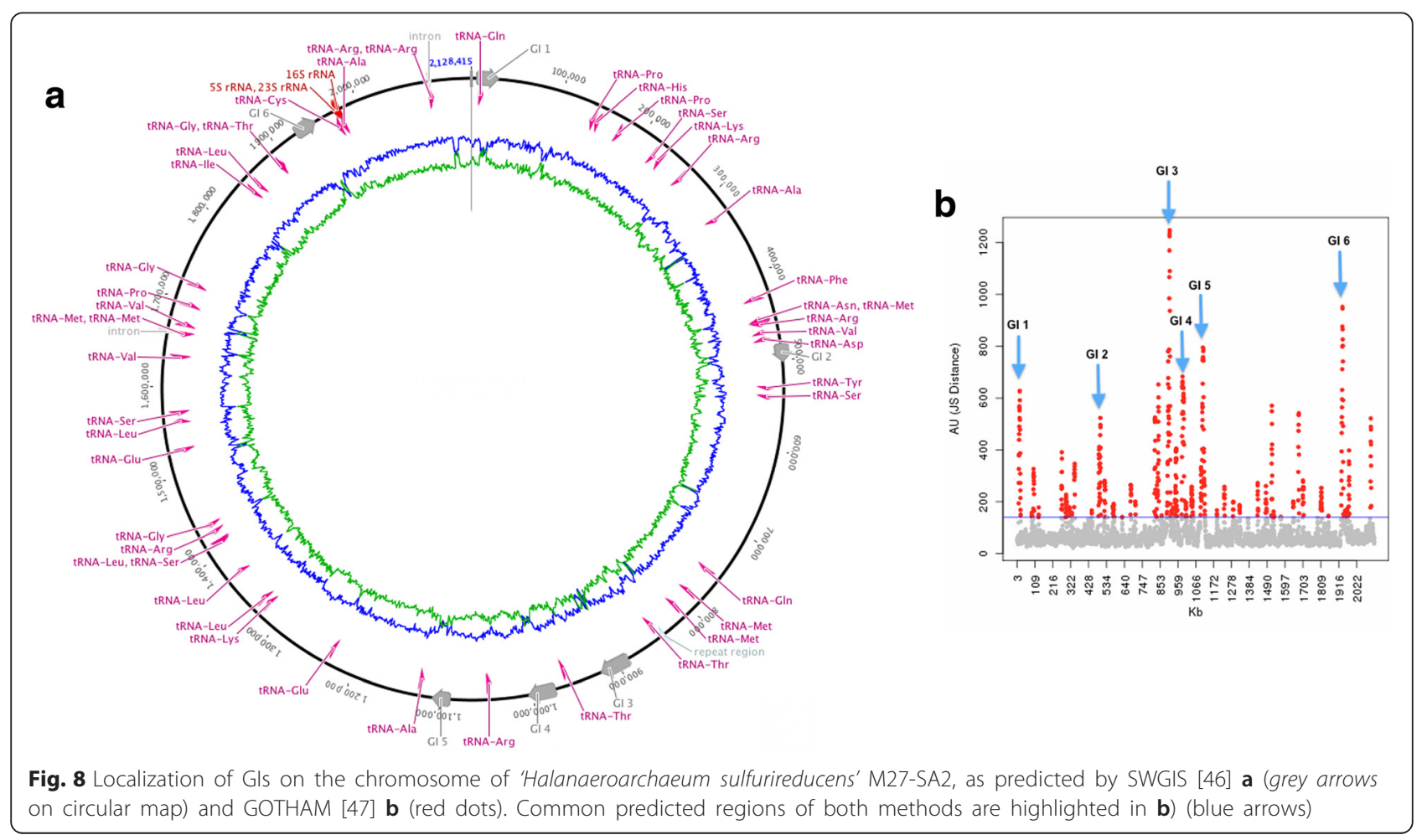


"viral" fragment of the prophage 1 as well as presence of a number of small ORFs of host origin interspaced by long non-coding regions with numerous stop codons on the right wings of its genome (see Fig. 7) would compromise release of viral particles. On the other hand, the pleomorphic nature of the prophage 1 could allow of formation viable particles with extended genomes, as viral packaging and release are driven by a budding vesicle from the plasma membrane, and the size of the genome therefore dictates the size of the vesicle [40]. According to this logic, CRISPR-Cas system of prophage 1 would not be active during lysogenic stage of infection as the expression of most of the lytic genes of a prophage are usually shut off [41], but could become active during lytic stage of infection and be used to overcome bacterial defense. Additional experiments can be designed and performed to distinguish between these two scenarios.

Another prophage 2 is $\sim 43.5 \mathrm{kbp}$ in length and containes 49 ORFs. One of the ORFs encodes a putative tape tail measure protein, which is a key feature of Siphoviridae morphological family. The closest homologues of ORFs of prophage 2 were related to several haloviruses: Bj1 (siphovirus that infects Halorubrum), phiCh1 (myovirus of Natrialba), HHTV1 (siphovirus of H. hispanica), HGTV1 (myovirus of Halogranum sp.), prophages in the Haloferax mucosum and Haloferax elongans genomes [42] and to environmental viral contigs (environmental halophages eHP-2, eHP-14, eHP-32, eHP-34, eHP-36). Interestingly, prophage 2 encodes an adenine-specific DNA methylase, which could be responsible for protection from host restriction endonucleases through methylation of the phage genome [43]. Prophage 2 is located next to a tRNA integration site and has a XerC/D integrase/recombinase gene on the opposite side of the genome: both features are always present as a part of a viable prophage. Archaeal tailed viral genomes integrated into cellular chromosomes have been identified before [44]. The fact that the closest host homologue in the database $(H$. sulfurireducens strain $\mathrm{HSR}_{2}{ }^{\mathrm{T}}$, accession number CP008874) doesn't contain a sequence of the prophage 2 suggests recent acquisition of this prophage. Viruses of Euryarchaeota encompass different morphologies, including spindle-shaped viruses (Salteproviridae), pleomorphic viruses (Pleolipoviridae), head-tailed viruses (Caudovirales), spherical viruses (Plasmaviridae), and unclassified icosahedral dsDNA viruses with an inner lipid layer [45]. Therefore, the presence of two different prophages in the same genome of $H$. sulfurireducens M27-SA2 suggests that archaea in hypersaline environemnts located at the bottom of the Mediterranean Sea are exposed to a constant threat of phage predation.

\section{Genomic islands}

Horizontally transferred genomic islands (GIs) in 'Halanaeroarchaeum sulfurireducens' M27-SA2 genome were determined by the SeqWord Gene Island Sniffer program [46] and by the GOHTAM online tool [47]. The results of both GI identification methods are shown in Fig. 8. Six putative GIs characterized by alternative oligonucleotide usage patterns were detected by SWGIS, while GOHTAM search returned many short region (overall 52, see Fig. 8b) in addition to the six previously identified, probably due to a lower default sensitivity threshold of the latter method. Predicted GIs harbored mainly hypothetical proteins, transposases, glycosyltransferases (many in the third GI), and other enzyme-coding genes (transport and metabolism), a tRNA in the first GI, while the sixth GI covers the prophage 2 region (see above), not present in Halanaeroarchaeum sulfurireducens' $\mathrm{HSR} 2^{\mathrm{T}}$.

\section{Conclusions}

In this manuscript we report on the complete genome sequence of 'Halanaeroarchaeum sulfurireducens' M27SA2 which is composed of a 2,129,244-bp chromosome and a $124,256-\mathrm{bp}$ plasmid. This is the first indication of the presence of obligate anaerobic sulfur-respiring haloarchaeon in deep-sea hypersaline anoxic lakes located on the seabed of Eastern Mediterranean Sea. This finding has significance for understanding of the biogeochemical functioning of these harsh ecosystems. Genome comparisons, analisys of amino acid biosynthesis pathways, CRISPR, phage-like elements and genomic islands was performed to understand the evolutionary success of Halanaeroarchaeum members in their adaptation to extreme biotopes around the world.

\section{Competing interests}

The authors declare that they have no competing interests.

\section{Authors' contributions}

EM carried out the genome scaffolding, final assembling and annotations, and registration to GenBank, performed the genomic islands analysis and drafted the manuscript. DS, IK and ST carried out the genome raw and contig sequencing, and reviewed the overall manuscript. AL carried out the phage-like elements analisys and drafted the relative section. EA, GLS, and VLC participated in the organism growth, isolation and DNA preparation. FS carried out the CRISPR analisys, the amino acid biosynthesis pathways, and drafted the relative sections. MMY conceived the study, and participated in its design and coordination and helped to draft and review the manuscript. All authors read and approved the final manuscript.

\section{Acknowledgements}

This work was supported by the European Commission's program, under the MAMBA (FP7-KBBE-2009-2B-226977), MicroB3 (FP7-OCEAN.2011-2-287589) and INMARE (Horizon 2020-634486) Projects and under Russian Academy of Science Program "Molecular and Cellular Biology". DS was supported by the RFBR grant 13-04-00049. We thank the master, crew, and participants to the cruises with research vessel RV Urania for their fruitful collaboration.

\section{Author details}

${ }^{1}$ Institute for Coastal Marine Environment, CNR, Messina, Italy. ${ }^{2}$ Winogradsky Institute of Microbiology, Russian Academy of Sciences, Moscow, Russia. ${ }^{3}$ Department of Biotechnology, Deft University of Technology, Delft, The Netherlands. ${ }^{4}$ Immanuel Kant Baltic Federal University, Kaliningrad, Russia. ${ }^{5}$ Institute of Molecular Genetics and Gene Biology, Russian Academy of Sciences, Moscow, Russia. 


\section{Received: 28 September 2015 Accepted: 3 May 2016}

\section{Published online: 13 May 2016}

\section{References}

1. Sorokin DY, Kublanov IV, Gavrilov SN, Rojo D, Roman P, Golyshin PN, Slepak VZ, Smedile F, Ferrer M, Messina E, La Cono V, Yakimov MM. Elemental sulfur and acetate can support life of a novel strictly anaerobic haloarchaeon. ISME J. 2016;10:240-52. doi:10.1371/journal.pone.0098229. PubMed.

2. Andrei AS, Banciu HL, Oren A. Living with salt: metabolic and phylogenetic diversity of archaea inhabiting saline ecosystems. FEMS Microbiol Lett. 2012;330:1-9. doi:10.1111/j.1574-6968.2012.02526.x. PubMed.

3. Blum JS, Kulp TR, Han S, Lanoil B, Saltikov CW, Stolz JF, Miller LG, Oremland RS. Desulfohalophilus alkaliarsenatis gen. nov., sp. nov., an extremely halophilic sulfate- and arsenate-respiring bacterium from Searles Lake, California. Extremophiles. 2012;16:727-42. doi:10.1007/s00792-012-0468-6. PubMed.

4. Blum JS, Han S, Lanoil B, Saltikov C, Witte B, Tabita FR, Langley S, Beveridge TJ, Jahnke L, Oremland RS. Ecophysiology of "Halarsenatibacter silvermanii" strain SLAS-1T, gen. nov., sp. nov., a facultative chemoautotrophic arsenate respirer from salt-saturated Searles Lake, California. Appl Environ Microbiol. 2009;75:1950-60. doi:10.1128/AEM.02614-08. PubMed.

5. Sorokin DY, Detkova EN, Muyzer G. Sulfur-dependent respiration under extremely haloalkaline conditions in soda lake 'acetogens' and the description of Natroniella sulfidigena sp. nov. FEMS Microbiol Lett. 2011:319:88-95. doi:10.1111/j.1574-6968.2011.02272.x. PubMed.

6. Antunes A, Taborda M, Huber R, Moissl C, Nobre MF, da Costa MS. Halorhabdus tiamatea sp. nov., a non-pigmented extremely halophilic archaeon from a deep-sea, hypersaline anoxic basin of the Red Sea, and emended description of the genus Halorhabdus. Int J Syst Evol Microbiol. 2008;58:215-20. doi:10.1099/ijs.0.65316-0. PubMed.

7. Bonete MJ, Martínez-Espinosa RM, Pire C, Zafrilla B, Richardson DJ. Nitrogen metabolism in haloarchaea. Saline Systems. 2008;4:9. doi:10.1186/1746-1448-4-9. PubMed.

8. Oren A, Trüper HG. Anaerobic growth of halophilic archaeobacteria by reduction of dimethylsulfoxide and trimethylamine N-oxide. FEMS Microbiol Lett. 1990;70:33-6. doi:10.1111/j.1574-6968.1990.tb03772.x. PubMed.

9. Oren A. Anaerobic growth of archaeobacteria by reduction of fumarate. J Gen Microbiol. 1991;137:1387-90. doi:10.1099/00221287-137-6-1387. PubMed.

10. Yakimov MM, La Cono V, Slepak VZ, La Spada G, Arcadi E, Messina E, et al. Microbial life in the Lake Medee, the largest deep-sea salt-saturated formation. Sci Rep. 2013;3:3554. doi:10.1038/srep03554. PubMed.

11. Urakawa H, Martens-Habbena W, Stahl DA. High abundance of ammoniaoxidizing archaea in coastal waters, determined using a modified DNA extraction method. Appl Environ Microbiol. 2010;76:2129-35. doi:10.1128/AEM.02692-09. Pubmed.

12. Zerbino DR, Birney E. Velvet: algorithms for de novo short read assembly using de Bruijn graphs. Genome Res. 2008;18:821-9. doi:10.1101/gr.074492.107. PubMed.

13. Delcher AL, Bratke KA, Powers EC, Salzberg SL. Identifying bacterial genes and endosymbiont DNA with Glimmer. Bioinformatics. 2007;23:673-9. doi:10.1093/bioinformatics/btm009. PubMed.

14. Lagesen K, Hallin PF, Rødland E, Stærfeldt HH, Rognes T, Ussery DW. RNAmmer: consistent and rapid annotation of ribosomal RNA genes. Nucleic Acids Res. 2007;35:3100-8. doi:10.1093/nar/gkm160. PubMed.

15. Lowe TM, Eddy SR. tRNAscan-SE: a program for improved detection of transfer RNA genes in genomic sequence. Nucleic Acids Res. 1997;25:955-64. doi:10.1093/nar/25.5.955. PubMed.

16. Tyson GW, Chapman J, Hugenholtz P, Allen EE, Ram RJ, Richardson PM, Solovyev W, Rubin EM, Rokhsar DS, Banfield JF. Community structure and metabolism through reconstruction of microbial genomes from the environment. Nature. 2004;428:37-43. doi:10.1038/nature02340. PubMed.

17. Toshchakov SV, Kublanov IV, Messina E, Yakimov MM, Golyshin PN. Genomic Analysis of Pure Cultures and Communities. In: Timmis KN, Nogales Fernández B, McGenity TJ, editors. Hydrocarbon and Lipid Microbiology Protocols: Cultivation. Springer Protocols Handbooks. 2015. p. 1-23. doi:10.1007/8623_2015_126. PubMed.

18. Rutherford K, Parkhill J, Crook J, Horsnell T, Rice P, Rajandream MA, Barrell B. Artemis: sequence visualization and annotation. Bioinformatics. 2001;16:944-5. doi:10.1093/bioinformatics/16.10.944. PubMed.

19. Altschul SF, Madden TL, Schäffer AA, Zhang J, Zhang Z, Miller W, Lipman DJ. Gapped BLAST and PSI-BLAST: a new generation of protein database search programs. Nucleic Acids Res. 1997;25:3389-402. doi:10.1093/nar/25.17.3389. Pubmed.
20. Carver TJ, Rutherford KM, Berriman M, Rajandream MA, Barrell BG, Parkhill J. ACT: the Artemis Comparison Tool. Bioinformatics. 2005;21:3422-3. doi:10.1093/bioinformatics/bti553. PubMed.

21. Kiełbasa SM, Wan R, Sato K, Horton P, Frith MC. Adaptive seeds tame genomic sequence comparison. Genome Res. 2011:21:487-93. doi:10.1101/gr.113985.11. PubMed.

22. Darling AC, Mau B, Blattner FR, Perna NT. Mauve: multiple alignment of conserved genomic sequence with rearrangements. Genome Res. 2004;14:1394-403. doi:10.1101/gr.2289704. PubMed.

23. Overbeek R, Begley T, Butler RM, Choudhuri JV, Chuang HY, Cohoon M, et al. The subsystems approach to genome annotation and its use in the project to annotate 1000 genomes. Nucleic Acids Res. 2005;33:5691-702. doi:10.1093/nar/gki866. PubMed.

24. Kanehisa M, Goto S, Sato Y, Kawashima M, Furumichi M, Tanabe M. Data, information, knowledge and principle: back to metabolism in KEGG. Nucleic Acids Res. 2014;42:D199-205. doi:10.1093/nar/gkt1076. PubMed.

25. Edgar RC. PILER-CR: fast and accurate identification of CRISPR repeats. BMC Bioinformatics. 2007:8:18. doi:10.1186/1471-2105-8-18. PubMed.

26. Grissa I, Vergnaud G, Pourcel C. CRISPRFinder: a web tool to identify clustered regularly interspaced short palindromic repeats. Nucleic Acids Res. 2007:35:W52-7. doi:10.1093/nar/gkm360. PubMed.

27. Pachiadaki MG, Yakimov MM, La Cono V, Leadbetter E, Edgcomb V. Unveiling microbial activities along the halocline of Thetis, a deep-sea hypersaline anoxic basin. ISME J. 2014;8:2478-89. doi:10.1038/ismej.2014.100. PubMed.

28. Narasingarao P, Podell S, Ugalde JA, Brochier-Armanet C, Emerson JB, Brocks JJ, Heidelberg KB, Banfield JF, Allen EE. De novo metagenomic assembly reveals abundant novel major lineage of Archaea in hypersaline microbial communities. ISME J. 2012;6:81-93. doi:10.1038/ismej.2011.78. PubMed.

29. Garcia-Heredia I, Martin-Cuadrado AB, Mojica FJ, Santos F, Mira A, Antón J, Rodriguez-Valera F. Reconstructing viral genomes from the environment using fosmid clones: the case of haloviruses. PLoS One. 2012;7:e33802. doi:10.1371/journal.pone.0033802. PubMed.

30. Dinsdale EA, Edwards RA, Hall D, Angly F, Breitbart M, Brulc JM, Furlan M, Desnues C, Haynes M, Li L. Functional metagenomic profiling of nine biomes. Nature. 2008;452:629-32. doi:10.1038/nature06810. PubMed.

31. Makarova KS, Haft DH, Barrangou R, Brouns SJ, Charpentier E, Horvath P, Moineau S, Mojica FJ, Wolf Yl, Yakunin AF, van der Oost J, Koonin EV. Evolution and classification of the CRISPR-Cas systems. Nat Rev Microbiol. 2011;9:467-77. doi:10.1038/nrmicro2577. PubMed.

32. Boujelben I, Yarza P, Almansa C, Villamor J, Maalej S, Antón J, et al. Virioplankton community structure in Tunisian solar salterns. Appl Environ Microbiol. 2012;78:7429-37. doi:10.1128/AEM.01793-12. PubMed.

33. Shah SA, Erdmann S, Mojica FJ, Garrett RA. Protospacer recognition motifs: mixed identities and functional diversity. RNA Biol. 2013;10:891-9. doi:10.4161/rna.23764. PubMed.

34. Fischer S, Maier LK, Stoll B, Brendel J, Fischer E, Pfeiffer F, Dyall-Smith M, Marchfelder A. An archaeal immune system can detect multiple protospacer adjacent motifs (PAMs) to target invader DNA. J Biol Chem. 2012;287:33351-63. doi:10.1074/jbc.M112.377002. PubMed.

35. Li M, Wang R, Xiang H. Haloarcula hispanica CRISPR authenticates PAM of a target sequence to prime discriminative adaptation. Nucleic Acids Res. 2014;42:7226-35. doi:10.1093/nar/gku389. PubMed.

36. Al-Attar S, Westra ER, van der Oost J, Brouns SJ. Clustered regularly interspaced short palindromic repeats (CRISPRs): the hallmark of an ingenious antiviral defense mechanism in prokaryotes. Biol Chem. 2011;392:277-89. doi:10.1515/BC.2011.042. PubMed.

37. Paul JH. Prophages in marine bacteria: dangerous molecular time bombs or the key to survival in the seas? ISME J. 2008;2:579-89. doi:10.1038/ismej.2008.35. PubMed.

38. Fouts DE. Phage_Finder: automated identification and classification of prophage regions in complete bacterial genome sequences. Nucleic Acids Res. 2006;34:5839-51. doi:10.1093/nar/gkl732. PubMed.

39. Seed KD, Lazinski DW, Calderwood SB, Camilli A. A bacteriophage encodes its own CRISPR/Cas adaptive response to evade host innate immunity. Nature. 2013:494:489-91. doi:10.1038/nature11927. PubMed.

40. Pietilä MK, Atanasova NS, Manole V, Liljeroos L, Butcher SJ, Oksanen HM, Bamford $\mathrm{DH}$. Virion architecture unifies globally distributed pleolipoviruses infecting halophilic archaea. J Virol. 2012;86:5067-79. doi:10.1128/JVI.06915-11. PubMed.

41. Abedon ST and Calendar RL (Eds.) The Bacteriophage, second edition, Oxford University Press, New York, 2005, Part 27, p. 409-447. 
42. Maier LK, Dyall-Smith M, Marchfelder A. The Adaptive Immune System of Haloferax volcanii. Life (Basel). 2015;5:521-37. doi:10.3390/life5010521. PubMed.

43. Murphy J, Mahony J, Ainswoth S, Nauta A, van Sinderen D. Bacteriophage Orphan DNA Methyltransferases: Insights from Their Bacterial Origin, Function, and Occurrence. Appl Environ Microbiol. 2013;79:7547-55. doi:10.1128/AEM.02229-13. PubMed.

44. Krupovic M, Forterre P, Bamford DH. Comparative analysis of the mosaic genomes of tailed archaeal viruses and proviruses suggests common themes for virion architecture and assembly with tailed viruses of bacteria. J Mol Biol. 2010;397:144-60. doi:10.1016/j.jmb.2010.01.037. PubMed.

45. Prangishvili. The wonderful world of Archaeal viruses. Annu Rev Microbiol. 2013;67:565-85. doi:10.1146/annurev-micro-092412-155633. PubMed.

46. Bezuidt O, Lima-Mendez G, Reva ON. SeqWord Gene Island Sniffer: a program to study the lateral genetic exchange among bacteria. World Acad Sci Eng Technol. 2009;58:1169-74. doi:10.1.1.193.5091. PubMed.

47. Ménigaud S, Mallet L, Picord G, Churlaud C, Borrel A, Deschavanne P. GOHTAM: a website for 'Genomic Origin of Horizontal Transfers, Alignment and Metagenomics'. Bioinformatics. 2012;28:1270-1. doi:10.1093/bioinformatics/bts118. PubMed.

48. Field D, Garrity G, Gray T, Morrison N, Selengut J, Sterk P, et al. Towards a richer description of our complete collection of genomes and metagenomes: the "Minimum Information about a Genome Sequence" (MIGS) specification. Nat Biotechnol. 2008;26:541-7. doi:10.1038/nbt1360. PubMed.

49. Woese $\mathrm{CR}$, Kandler $\mathrm{O}$, Wheelis ML. Towards a natural system of organisms: proposal for the domains Archaea, Bacteria, and Eucarya. Proc Natl Acad Sci U S A. 1990;87:4576-9. doi:10.1073/pnas.87.12.4576. PubMed.

50. Garrity GM, Phylum HJG, All. Euryarchaeota phy. nov. In: Garrity GM, Boone DR, Castenholz RW, editors. Bergey's Manual of Systematic Bacteriology, vol. 1. 2nd ed. New York: Springer; 2001. p. 211-355.

51. List Editor. Validation List no. 85. Validation of publication of new names and new combinations previously effectively published outside the IJSEM. Int J Syst Evol Microbiol. 2002;52:685-90. doi:10.1099/ijs.0.02358-0. PubMed.

52. Grant WD, Kamekura M, McGenity TJ, Class VA, III. Halobacteria class. nov. In: Garrity GM, Boone DR, Castenholz RW, editors. Bergey's Manual of Systematic Bacteriology, vol. 1. 2nd ed. New York: Springer; 2001. p. 294.

53. Grant WD, Larsen H, Group III. Extremely halophilic archaeobacteria. Order Halobacteriales ord. nov. In: Holt JG, editor. Bergey's Manual of Systematic Bacteriology, Volume 3. Baltimore: Williams \& Wilkins; 1989. p. 2216-28.

54. The nomenclatural types of the orders Acholeplasmatales, Halanaerobiales, Halobacteriales, Methanobacteriales, Methanococcales, Methanomicrobiales, Planctomycetales, Prochlorales, Sulfolobales, Thermococcales, Thermoproteales and Verrucomicrobiales are the genera Acholeplasma, Halanaerobium, Halobacterium, Methanobacterium, Methanococcus, Methanomicrobium, Planctomyces, Prochloron, Sulfolobus, Thermococcus, Thermoproteus and Verrucomicrobium, respectively. Opinion 79. Int J Syst Evol Microbiol. 2005:55:517-518. PubMed doi:10.1099/ijs.0.63548-0.

55. List Editor. Validation List no. 31. Validation of the publication of new names and new combinations previously effectively published outside the IJSB. Int J Syst Bacteriol. 1989;39:495-7. doi:10.1099/00207713-39-4-495. PubMed.

56. Skerman VBD, McGowan V, Sneath PHA. Approved Lists of Bacterial Names. Int J Syst Bacteriol. 1980;30:225-420. doi:10.1099/00207713-30-1-225. PubMed.

57. Gibbons NE, Family V. Halobacteriaceae Fam. nov. In: Buchanan RE, Gibbons NE, editors. Bergey's Manual of Determinative Bacteriology. 8th ed. Baltimore: The Williams and Wilkins Co.; 1974. p. 269-73.

58. Ashburner M, Ball CA, Blake JA, Botstein D, Butler H, Cherry JM, Davis AP, Dolinski K, Dwight SS, Eppig JT, et al. Gene Ontology: tool for the unification of biology. Nat Genet. 2000;25:25-9. doi:10.1038/75556. PubMed.

59. Swofford DL. PAUP*: Phylogenetic analysis using Parsimony (and other methods) 4.0 Beta. Sinauer Associates, Inc.; 2002. ISBN 978-0-87893-806-3

60. Carver TJ, Thomson N, Bleasby A, Berriman M, Parkhill J. DNAPlotter: circular and linear interactive genome visualization. Bioinformatics. 2009;25:119-20. doi:10.1093/bioinformatics/btn578. PubMed.

\section{Submit your next manuscript to BioMed Central and we will help you at every step:}

- We accept pre-submission inquiries

- Our selector tool helps you to find the most relevant journal

- We provide round the clock customer support

- Convenient online submission

- Thorough peer review

- Inclusion in PubMed and all major indexing services

- Maximum visibility for your research

Submit your manuscript at www.biomedcentral.com/submit
Ciomed Central 